\title{
Correction to: Linking Abiotic Variables with Macrofaunal and Meiofaunal Abundance and Community Structure Patterns on the Gulf of Mexico Continental Slope
}

Paul A. Montagna, Jeffrey G. Baguley, Michael G. Reuscher, Gilbert T. Rowe, and Terry L. Wade

\section{Correction to:}

Chapter 7 in: S. A. Murawski et al. (eds.), Scenarios and Responses to Future Deep Oil Spills, https://doi.org/10.1007/978-3-030-12963-7_7

The book was inadvertently published without including the name of Michael G. Reuscher as a co-author of Chapter 7. This has now been updated and the correct order of authors is as follows:

Paul A. Montagna, Jeffrey G. Baguley, Michael G. Reuscher, Gilbert T. Rowe, and Terry L. Wade 